\section{Assessment of Chlorophyll and Nitrate Meters as Field Tissue Nitrogen Tests for Cabbage, Onions, and Carrots}

\author{
Sean M. Westerveld, ${ }^{1}$ \\ Alan W. McKeown, ${ }^{2}$ \\ Cynthia D. Scott-Dupree, ${ }^{3}$ \\ and Mary Ruth McDonald ${ }^{4}$
}

Additional Index wORds. SPAD, Cardy, plant analysis, nutrient management

SUmmary. Nutrient management legislation has prompted an evaluation of alternative nitrogen $(\mathrm{N})$ management techniques. SPAD (Soil Plant Analysis Development) chlorophyll and Cardy nitrate $\left(\mathrm{NO}_{3}^{-}\right)$meters were evaluated for their potential as tissue nitrogen tests in cabbage (Brassica olevacea var. capitata), onions (Allium cepa), and carrots (Daucus carota subsp. sativus). Cabbage, carrots, and onions were grown on both organic and mineral soils in Ontario, Canada in 2000 and 2001. Nitrogen was applied at five rates to cabbage and carrots and three rates to onions ranging from 0 to $200 \%$ of current provincial recommended $\mathrm{N}$ rates. In an additional treatment, $50 \%$ of the recommended rate was applied preplant and sidedress $\mathrm{N}$ applications of $40 \mathrm{~kg} \cdot \mathrm{ha}^{-1}$ (35.7 lb/acre) were applied when SPAD chlorophyll meter readings fell below 95 (2000) and 97\% (2001) of the highest $\mathrm{N}$ rate treatment. Yields were generally unaffected by $\mathrm{N}$ rate, except in cabbage in 2000, suggesting adequate $\mathrm{N}$ was present in most treatments. SPAD chlorophyll meter

\footnotetext{
1,2,4 Department of Plant Agriculture, ${ }^{3}$ Department of Environmental Biology, University of Guelph, Guelph, Ont., N1G 2Wl Canada.

This paper is a portion of a master's thesis submitted by S.M. Westerveld. We thank Kevin Vander Kooi, Cathy Bakker and the research station staff for their assistance. We also thank John Lauzon and Ivan O'Halloran for reviewing this paper. Funding provided by the Agricultural Adaptation Council through the support of the Ontario Fruit and Vegetable Grower's Association.

${ }^{1}$ Graduate student.

${ }^{2,3}$ Associate professor.

${ }^{4}$ Assistant professor.
}

readings were highly variable among soil types, cultivars, and years. Chlorophyll readings reached a plateau in adequately fertilized crops in many instances. Cardy readings were less variable among soil types, cultivars, and years. The relationship between $\mathrm{N}$ rate and sap $\mathrm{NO}_{3}-\mathrm{N}$ concentration was generally linear. The results suggest that the use of a well-fertilized reference plot is most appropriate for the SPAD meter on these vegetable crops, while the use of region-specific critical $\mathrm{NO}_{3}-\mathrm{N}$ concentrations was most appropriate for the Cardy $\mathrm{NO}_{3}{ }^{-}$meter. Both meters would be cost advantageous when over 500 samples are tested. The meters were generally easy to use, except for the SPAD meter on carrots. The meters have potential for $\mathbf{N}$ management of vegetable crops under Ontario growing conditions.

$\mathrm{E}$ fficient use of nitrogen has become increasingly important for both environmental and economic aspects of crop production. Chlorophyll and nitrate $\left(\mathrm{NO}_{3}^{-}\right)$meters have the potential to provide a rapid in-field determination of crop nitrogen (N) status that could be used to improve $\mathrm{N}$ use in the field. While many studies have reported correlations between meter readings and laboratory results, there has been little information on the practical use of these meters in these vegetable crops. Previously, we reported a correlation between meter readings and laboratory tissue total $\mathrm{N}$ and $\mathrm{NO}_{3}-\mathrm{N}$ analyses for both meters at selected growth stages for onions, carrots, and cabbage (Westerveld et al., 2003a). However, we have not focussed on use of these meters in the field and their potential as $\mathrm{N}$-monitoring tools for these vegetable crops.

In-field electrode technology such as the Cardy $\mathrm{NO}_{3}^{-}$(Horiba Co., Kyoto, Japan) meter can provide both accurate and timely $\mathrm{N}$ status information for a crop through direct measurement of the $\mathrm{NO}_{3}-\mathrm{N}$ concentration of xylem sap. The Cardy $\mathrm{NO}_{3}^{-}$meter can be used with undiluted plant sap (Rosen et al., 1996), which allows the user to test $\mathrm{NO}_{3}{ }^{-}$sap levels directly in the field. Generally, petiole or midrib sap is used as the sap source in most crops because $\mathrm{NO}_{3}^{-}$concentrations in the plant are often highest in these parts due to $\mathrm{NO}_{3}{ }^{-}$transport through the xylem (Maynard and Barker, 1972). Onion roots are used because of the 
stable $\mathrm{NO}_{3}{ }^{-}$concentrations in the root xylem (Sullivan, 1986).

The Cardy $\mathrm{NO}_{3}{ }^{-}$meter has been used successfully for sap analysis in many crops (Delgado and Follett, 1998; Hartz et al., 1993; Warncke, 1996; Westcott et al., 1993). Meter readings were correlated with dry matter $\mathrm{NO}_{3}{ }^{-}$determinations in broccoli (Brassica oleracea var. italica)(Hartz et al., 1993; Kubota et al., 1997) and cauliflower (Brassica oleracea var. botrytis)(Kubota et al., 1996). Cardy $\mathrm{NO}_{3}-\mathrm{N}$ readings were shown to be highly correlated with laboratory results in many growth stages for cabbage, onions, and carrots in our previous study (Westerveld et al., 2003a). However, Cardy meter readings have not been evaluated to determine their best possible use for $\mathrm{N}$ management of the crops.

Problems with the use of the Cardy $\mathrm{NO}_{3}^{-}$meter for the determination of crop $\mathrm{N}$ sufficiency have been reported in corn (Zea mays), wheat (Triticum aestivum), and barley (Hordeum vulgare) due to aging of the sampled material and variability among sites
(Geypens and Vandendriessche, 1996; Hartz et al., 1993). Sap $\mathrm{NO}_{3}-\mathrm{N}$ levels in the field are also highly variable on a day-to-day basis (Coltman, 1988).

A rapid procedure for an evaluation of the chlorophyll content of individual leaves is possible using the Minolta SPAD-502 chlorophyll meter (Minolta Camera Co., Ramsey, N.J.). While individual SPAD measurements can be affected by diseases and nutrient disorders, readings require only a few seconds to perform, and as a result many leaves can be assessed in a short period of time. SPAD chlorophyll meter readings have been correlated with tissue total $\mathrm{N}$ concentrations in many grasses (Poaceae) (Blackmer and Schepers, 1994; Dwyer et al., 1991; Follett et al., 1992; Reeves et al., 1993; Rodriguez and Miller, 2000; Turner and Jund, 1991). In addition, chlorophyll levels have been correlated with total N concentrations in cotton (Gossypium hirsutum)(Wood et al., 1992), eggplant (Solanum melongena)(LopezCantarero et al., 1994), and apples (Malus $\times$ domestica)(Neilsen et al., 1995).
A poor correlation between SPAD meter readings and laboratory results for carrots and onions was shown in our previous study (Westerveld et al., 2003a). However, the reason for the lack of correlation could be attributed to a plateau in SPAD readings at high $\mathrm{N}$ rates without a corresponding plateau in tissue $\mathrm{N}$ concentrations due to luxury $\mathrm{N}$ consumption. For cabbage, there was a good correlation between SPAD meter readings and laboratory results when sufficient readings were taken (Westerveld et al., 2003a). However, the potential use of the SPAD meter for scheduling fertilizer application has not been extensively tested.

Problems with the SPAD meter have also been reported. Considerable replication was necessary to show treatment differences in corn plants (Dwyer et al., 1991). In wheat and st. augustinegrass (Stenotaphrum secondatum), chlorophyll measurements were not well correlated with total $\mathrm{N}$ concentrations (Reeves et al., 1993; Rodriguez and Miller, 2000). In tomatoes (Lycopersicon esculentum), SPAD chlorophyll readings were af-

Table 1. Nitrogen (N) treatments applied to cabbage, onions, and carrots on mineral and organic soil in 2000 and 2001.

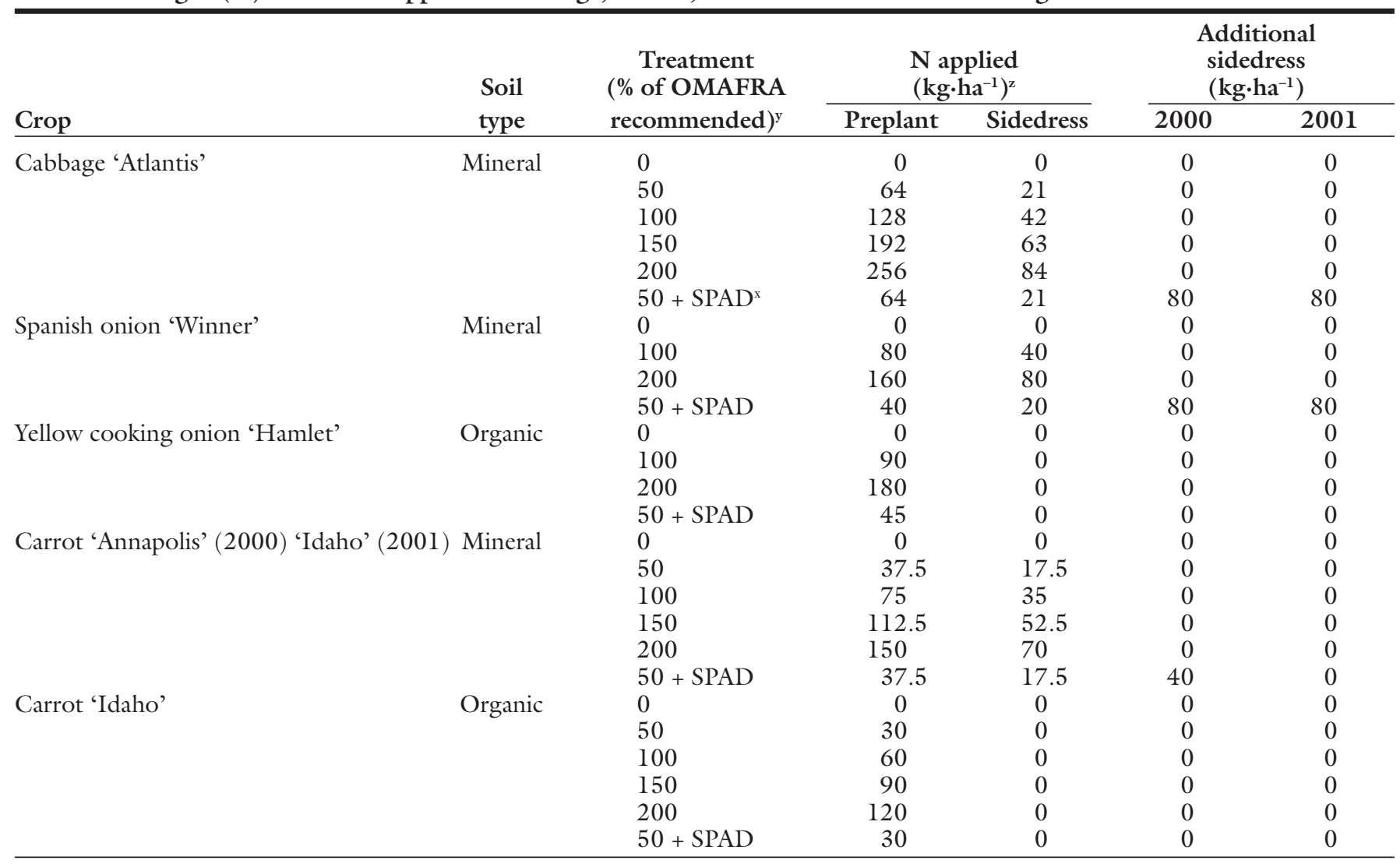

${ }^{\mathrm{z}} \mathrm{l} .0 \mathrm{~kg} \cdot \mathrm{ha}^{-1}=0.89 \mathrm{lb} / \mathrm{acre}$

YMAFRA = Ontario Ministry of Agriculture, Food, and Rural Affairs, 2000.

xidedresses of $40 \mathrm{~kg} \cdot \mathrm{ha}^{-1} \mathrm{~N}$ applied when SPAD chlorophyll meter readings fell below 95 (2000) and 97\% (2001) of the highest N rate treatment (cabbage 2000: 12 July and 2 Aug.; cabbage 2001: 6 June and 20 June; onion mineral 2000: 23 Aug. and 11 Sept.; onion mineral 2001: 30 May and 11 July; carrot mineral 2000: 12 Sept.). 
fected by cultivar (Sandoval-Villa et al., 2000).

The objective of this study was to assess the potential of the SPAD chlorophyll and Cardy $\mathrm{NO}_{3}^{-}$meters as a tissue $\mathrm{N}$ test for onions, carrots, and cabbage based on their cost, ease of use, time required for an adequate test, ability to assist in the scheduling of fertilization $\mathrm{N}$ applications, and the use of critical meter readings as an indicator of $\mathrm{N}$ sufficiency.

\section{Materials and methods}

Carrots and onions were grown in organic soil at the University of Guelph-Muck Crops Research Station (lat. $44^{\circ} 15^{\prime} \mathrm{N}$, long. $77^{\circ} 90^{\prime} \mathrm{W}$ ), Holland/Bradford Marsh, Ontario in 2000 and 2001. Yellow cooking onions, 'Hamlet', were direct seeded [36 seeds $/ \mathrm{m}(11.0$ seeds $/ \mathrm{ft})]$ on 5 May (2000) and 7 May (2001) in eight-row plots (two rows 'Hamlet' plus six guard rows), with $40-\mathrm{cm}$ (15.7inch) row spacing and $5 \mathrm{~m}(16.4 \mathrm{ft})$ in length. Total yield was assessed after field curing on 18 Sept. (2000) and 10 Sept. (2001) by hand-harvesting a 2.3 -m-long $(7.59-\mathrm{ft})$ section of an inside row of each plot. 'Idaho' carrots were direct seeded [ 80 seeds $/ \mathrm{m}(24.4$ seeds/ft)] on 28 July (2000) and 24 May (2001) in four hill plots, (two hills 'Idaho' plus two guard rows), with hills $20 \mathrm{~cm}$ (7.9 inches) high, 86 $\mathrm{cm}$ (33.9 inches) apart, $5 \mathrm{~m}$ in length. Total yield was assessed on 17 Nov. (2000) and 25 Oct. (2001) by handharvesting a $2.3-\mathrm{m}$ section of an inside row of each plot. The organic soil ( $\mathrm{pH}$ 6.5), a Hemic Histosol, contained 60\% organic matter.

Cabbage, carrots, and onions were grown on mineral soil at the University of Guelph-Simcoe Campus (lat. $42^{\circ} 51^{\prime} \mathrm{N}$, long. $\left.80^{\circ} 16^{\prime} \mathrm{W}\right)$, Simcoe, Ontario in 2000 and 2001. 'Atlantis' cabbage was seeded in 200-cell plastic plug trays on 10 May (2000) and 27 Apr. (2001), and transplanted into the field on 9 June (2000) and 30 May (2001). Cabbage plots consisted of four rows, spaced $75 \mathrm{~cm}$ (29.5 inches) apart, $7 \mathrm{~m}(23.0 \mathrm{ft})(2000)$ and $9 \mathrm{~m}$ $(29.5 \mathrm{ft})(2001)$ in length, and within row spacing of $45 \mathrm{~cm}$ (17.7 inches). Total yield was assessed at maturity on 16 Aug., 30 Aug., and 11 Sept. (2000) and 17 Aug. and 5 Sept. (2001) by hand-harvesting mature heads from a 4-m-long (13.1-ft) section of the middle two rows of each plot.
'Winner' spanish onions were direct seeded $[10$ seeds $/ \mathrm{m}(3.3$ seeds $/ \mathrm{ft})]$ on 14 June (2000) and seeded in 200-cell plastic plug trays on 19 Mar. and transplanted 16 May (2001) in four row plots, with row spacing of $75 \mathrm{~cm}$, within row spacing of $15 \mathrm{~cm}$ (5.9 inches), and $7 \mathrm{~m}$ (2000) and 6.5 $\mathrm{m}(21.32 \mathrm{ft})(2001)$ in length. Total yield was assessed after field curing on 16 Oct. by hand-harvesting a 5-m section of an inside row of each plot (2000) and 21 Aug. from a 3.5-m $(11.48-\mathrm{ft})$ section of the inside two rows of each plot (2001). 'Annapolis' (2000) and 'Idaho' (2001) carrots were direct seeded $(80$ seeds $/ \mathrm{m}$ ) on 14 June (2000) and 13 June (2001) in three row plots, with row spacing of $35 \mathrm{~cm}$ (13.8 inches), $7 \mathrm{~m}$ in length, and with three guard rows between plots. Total yield was assessed on 6 Nov. (2000) and 24 Oct. (2001) by hand-harvesting a $2-\mathrm{m}(6.6-\mathrm{ft})$ section of each row. The mineral soil ( $\mathrm{pH} 5.8$ to 7.0 ), a Typic Hapludalf, had organic matter content between $0.5 \%$ and $1.5 \%$.

Nitrogen treatments are summarized in Table 1 . Nitrogen rates were based on the current provincial recommendations for each crop and soil type (Ontario Ministry of Agriculture, Food, and Rural Affairs, 2000). In one treatment for all crops and both soil types, $50 \%$ of the recommended rate of $\mathrm{N}$ was applied preplant and $40-\mathrm{kg} \cdot \mathrm{ha}^{-1}$ sidedresses were applied when Minolta SPAD-502 chlorophyll meter readings fell below 95\% (2000) and 97\% (2001) of the highest $\mathrm{N}$ rate treatment (Table 1). The 95\% threshold was based on guidelines provided with the meter, and this was adjusted to $97 \%$ in 2001 in order to detect deficiencies before a loss in yield potential occurred. In all plots $\mathrm{N}$ was broadcast by hand using calcium ammonium nitrate preplant and potassium nitrate for sidedress applications.

A Horiba Cardy $\mathrm{NO}_{3}{ }^{-}$meter was used to assess the $\mathrm{NO}_{3}-\mathrm{N}$ concentration of sap, and a Minolta SPAD-502 chlorophyll meter was used to assess overall tissue $\mathrm{N}$ status. Meter readings were taken from plants that were sampled at the cupping, early heading, and mature growth stages for cabbage, early (49 to $69 \mathrm{~d}$ after seeding), midseason (7l to $98 \mathrm{~d}$ after seeding), and late (97 to $126 \mathrm{~d}$ after seeding) growth stages for carrots (only early and midseason stage on organic soil in 2000), and the five-leaf, early bulbing, and mature growth stages for onions. On cabbage, Cardy meter $\mathrm{NO}_{3}-\mathrm{N}$ readings were taken from sap extracted from the midrib of one recently mature leaf using a garlic press. Cardy meter $\mathrm{NO}_{3}-\mathrm{N}$ readings were taken from sap extracted from three to five petioles of recently mature leaves of carrots. Each petiole was taken from a separate plant. Cardy meter $\mathrm{NO}_{3}-\mathrm{N}$ readings in onions were taken from sap extracted from the harvestable roots of a single plant. Two Cardy readings per replicate were taken in 2000 and this was doubled in 2001, and each reading was taken from a separate sample. The replaceable sensor of the Cardy $\mathrm{NO}_{3}{ }^{-}$meter was replaced approximately every 100 (carrots) to 200 (onions and cabbage) readings. SPAD chlorophyll meter readings were taken from mature leaves in all crops, and five readings per replication were taken from separate plants in 2000 and this was doubled in 2001.

At the same growth stage as meter readings, tissue samples for laboratory analysis were collected from five recently mature wrapper leaves in cabbage, 30 recently mature petioles in carrots, and 15 recently mature leaf blades in onions. Each leaf or petiole sample was taken from a separate plant. Tissue samples from three replications (four replications in the first sample date in 2001) were oven dried [70 ${ }^{\circ} \mathrm{C}\left(158.0^{\circ} \mathrm{F}\right)$ for $48 \mathrm{~h}$ ] and sent to A\&L Laboratories East, Inc. (London, Ontario, Canada) in 2000 and University of Guelph Soil and Nutrient Laboratory (Guelph, Ontario, Canada) in 2001 for both total $\mathrm{N}$ analysis and $\mathrm{NO}_{3}-\mathrm{N}$ analysis. The laboratory used a potassium chloride $(\mathrm{KCl})$ extraction method and automated colorimetric analysis for tissue analysis (Maynard and Kalra, 1993).

All plots were arranged as a randomized complete block design with four replications. Statistical analysis of the data was conducted using the GLM and Univariate procedure of SAS Version 8.0 (SAS Institute, Cary, N.C.), and the linear models section of Statistix V.4.1. A type I error rate of 0.05 or less was considered to be statistically significant in all statistical tests.

\section{Results and discussion}

FERTILIZER SCHEDULING WITH THE SPAD METER. Testing of the SPAD chlorophyll meter using a well-fertilized reference plot was problematic in 
Table 2. Effect of nitrogen $(\mathrm{N})$ rate and timing on the total yield of cabbage, carrots, and onions grown on mineral and organic soil in 2000 and 2001.

\begin{tabular}{|c|c|c|c|c|c|}
\hline \multirow{3}{*}{$\begin{array}{l}\mathrm{N} \text { rate } \\
(\% \text { of OMAFRA } \\
\text { recommended })^{\mathrm{y}}\end{array}$} & \multicolumn{5}{|c|}{ Yield $\left(t \cdot h a^{-1}\right)^{z}$} \\
\hline & \multirow{2}{*}{$\begin{array}{c}\text { Cabbage } \\
\begin{array}{c}\text { Mineral } \\
\text { soil }^{\mathrm{x}}\end{array} \\
\end{array}$} & \multicolumn{2}{|c|}{ Onions } & \multicolumn{2}{|c|}{ Carrots } \\
\hline & & $\begin{array}{c}\text { Mineral } \\
\text { soil }^{w}\end{array}$ & $\begin{array}{c}\text { Organic } \\
\text { soil }^{w}\end{array}$ & $\begin{array}{c}\text { Mineral } \\
\text { soil }^{w}\end{array}$ & $\begin{array}{c}\text { Organic } \\
\text { soil }^{w}\end{array}$ \\
\hline \multicolumn{6}{|l|}{2000} \\
\hline 0 & $36.3 \mathrm{a}^{\mathrm{v}}$ & $9.4^{\mathrm{Ns}}$ & $40.9^{\mathrm{Ns}}$ & $64.1^{\mathrm{Ns}}$ & $25.8^{\mathrm{Ns}}$ \\
\hline 50 & $63.6 \mathrm{bc}$ & --- & --- & 79.8 & 22.8 \\
\hline 200 & $69.6 \mathrm{c}$ & 9.7 & 41.4 & 74.6 & 19.2 \\
\hline $50+\mathrm{SPAD}^{\mathrm{u}}$ & $51.6 \mathrm{~b}$ & 5.6 & 36.9 & 74.8 & 23.6 \\
\hline \multicolumn{6}{|l|}{2001} \\
\hline 0 & $59.2^{\mathrm{Ns}}$ & $18.2^{\mathrm{Ns}}$ & $98.0^{\mathrm{Ns}}$ & $47.4^{\mathrm{Ns}}$ & $95.3^{\mathrm{Ns}}$ \\
\hline 50 & 63.8 & --- & --- & 49.7 & 92.8 \\
\hline 100 & 57.9 & 16.9 & 80.5 & 40.6 & 89.1 \\
\hline
\end{tabular}

${ }^{\mathrm{z}} 1.0 \mathrm{t} \cdot \mathrm{ha}^{-1}=0.45$ ton/acre.

OMAFRA = Ontario Ministry of Agriculture, Food, and Rural Affairs, 2000

xegression statistics for 2000 and for the $\mathrm{N}$ rates only: total yield: $R^{2}=0.61, P=0.0003$, total yield $=39.16+0.4114 \mathrm{~A}-0.00133 \mathrm{~A}^{2}$; where $\mathrm{A}=\mathrm{N}$ application rate $(\%$ of OMAFRA recommended $\mathrm{N}$ rate). Linear and quadratic regression analysis not significant for 2001 .

"Linear and quadratic regression analysis not significant for either year.

"Numbers in a column for each year followed by the same letter are not significantly different at $P \leq 0.05$, Fisher's protected least significant difference test; Ns Nonsignificant.

${ }^{u} \mathrm{SPAD}=40 \mathrm{~kg} \cdot \mathrm{ha}^{-1}(35.7 \mathrm{lb} / \mathrm{acre}) \mathrm{N}$ sidedress applied when SPAD chlorophyll meter readings fell below 95 (2000) and $97 \%$ of the highest $\mathrm{N}$ rate treatment.

Table 3. Comparison of SPAD chlorophyll meter readings to laboratory tissue total nitrogen (N) concentrations at three growth stages for cabbage grown on mineral soil in 2000 and 2001.

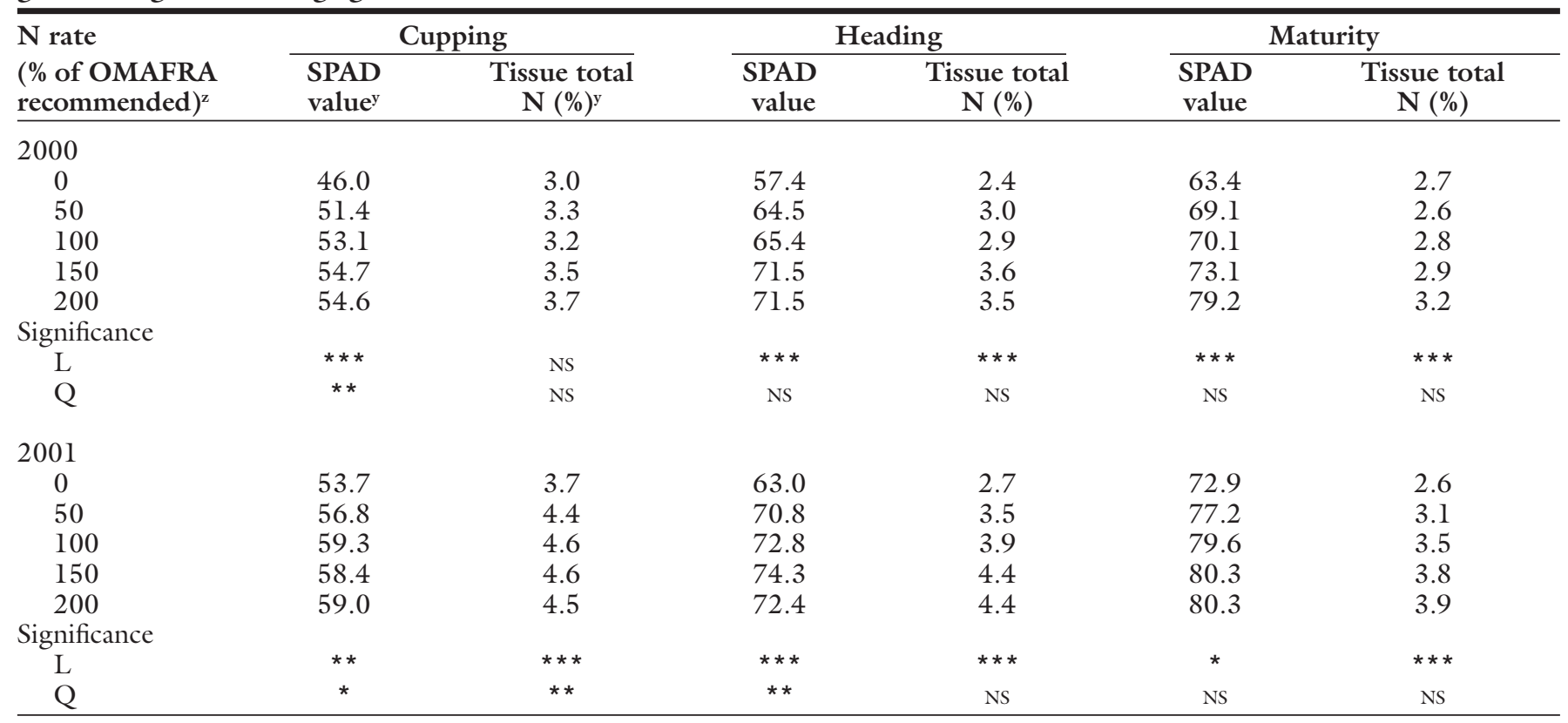

${ }^{z}$ OMAFRA = Ontario Ministry of Agriculture, Food, and Rural Affairs, 2000

ySPAD value $=$ Minolta SPAD -502 chlorophyll meter reading; tissue total $\mathrm{N}=$ percent tissue total $\mathrm{N}$ content on a dry weight basis as determined by a laboratory. Ns,*,**,*** Nonsignificant or significant at $P=0.05,0.01$, and 0.001 , respectively. $\mathrm{L}=$ linear; $\mathrm{Q}=$ quadratic.

many cases because of a lack of yield differences among the $\mathrm{N}$ rates tested in most plots (Table 2 ). The only plot in which nitrogen affected yield was in cabbage in 2000 where yield increased up to $155 \%$ of the recommended rate (Table 2). However, in both years, cabbage maturity was delayed up to 3 weeks by $\mathrm{N}$ rates at or below the recommended rate, suggesting a $\mathrm{N}$ deficiency occurred in both years (Westerveld et al., 2003b). In all organic soil plots and for carrots in 2001 on mineral soil, the SPAD meter was effective in preventing excess $\mathrm{N}$ application. In addition, the SPAD meter effectively detected a N deficiency for cabbage in both years, but sidedress applications based on the meter readings were too late to recover full yield potential. For onions on min- eral soil in both years and carrots on mineral soil in 2000 , the SPAD meter detected a $\mathrm{N}$ deficiency and sidedress $\mathrm{N}$ was applied when no $\mathrm{N}$ deficiency was present as indicated by a lack of differences in yield. In 2000 , for both crops, the $\mathrm{N}$ deficiencies detected by the SPAD meter occurred after 23 Aug. (Table 1), which suggests that meter reading comparisons with the 
Table 4. Comparison of SPAD chlorophyll meter readings to laboratory tissue total nitrogen (N) concentrations at three growth stages for onions grown on mineral and organic soil in 2000 and 2001.

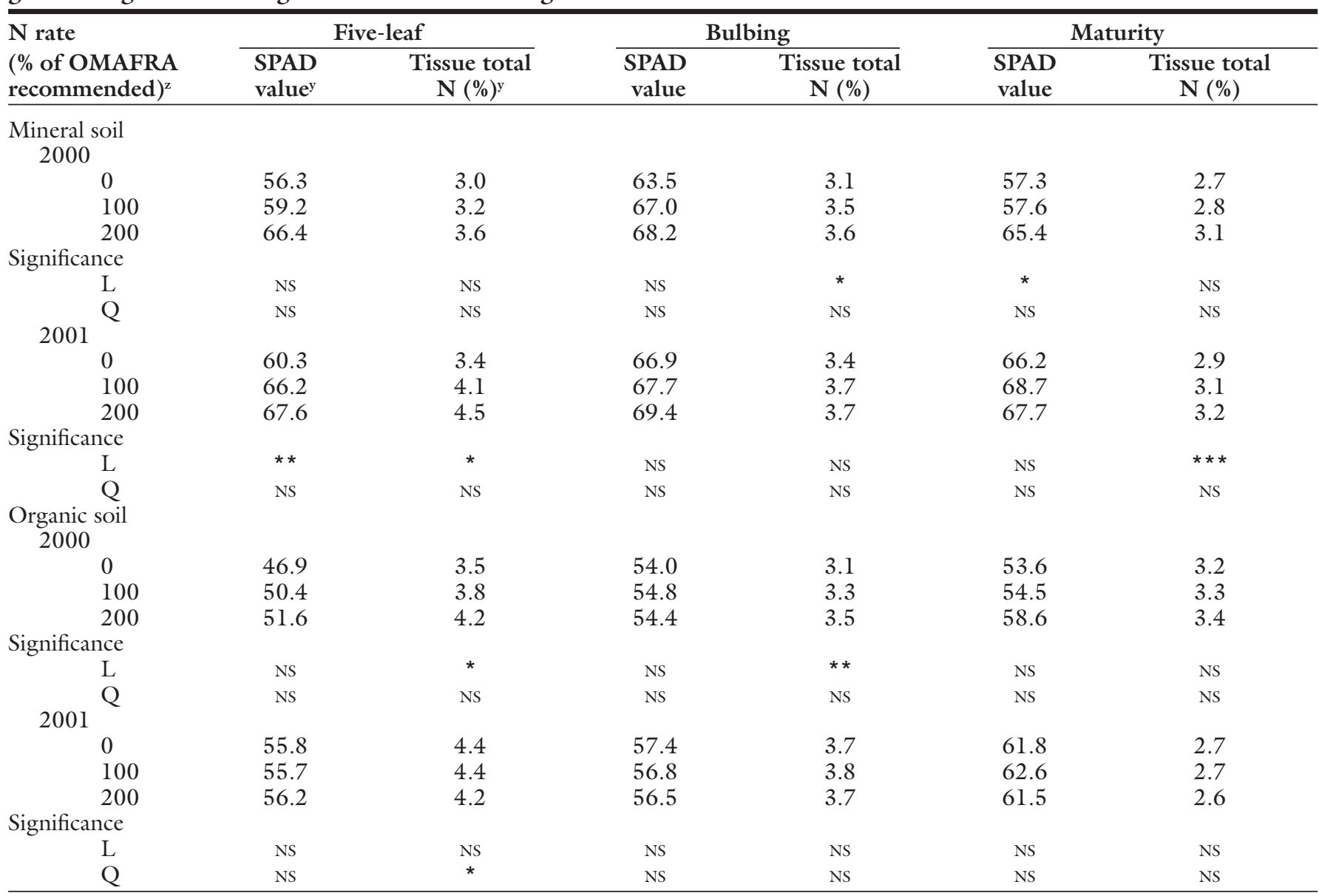

${ }^{2}$ OMAFRA = Ontario Ministry of Agriculture, Food, and Rural Affairs, 2000

${ }^{y}$ SPAD value $=$ Minolta SPAD -502 chlorophyll meter reading; tissue total $\mathrm{N}=$ percent tissue total $\mathrm{N}$ content on a dry weight basis as determined by a laboratory. Ns, $, * * *, * * *$ Nonsignificant or significant at $P=0.05,0.01$, and 0.001 , respectively. $\mathrm{L}=$ linear; $\mathrm{Q}=$ quadratic.

well-fertilized reference plot and fertilizer applications should not occur later than $70 \mathrm{~d}$ after seeding for both crops. Therefore, although yield differences were minimal in these plots, the SPAD meter and a well-fertilized reference plot successfully detected $\mathrm{N}$ deficiency or $\mathrm{N}$ sufficiency in most cases, but the thresholds used and the amount and timing of fertilizer sidedresses applied may have to be adjusted.

SPAD Chlorophyll Meter ReADINGS. SPAD chlorophyll readings generally increased as plant age increased in cabbage and to a lesser extent in 'Winner' spanish onions (Tables 3 and 4). Unlike in grain crops, it was not possible to test the same mature leaf consistently because mature leaves of all three crops senesce during the growing season. Consequently, as the readings shifted to newer mature leaves, the readings increased as the leaves became larger and thicker. This effect was not evident for carrots and 'Hamlet' yellow cooking onions (Tables 4 and 5). SPAD readings also appear to be affected by soil type and disease pressures. In 2001, when 'Idaho' carrots were grown on both soil types, readings generally were similar between the two soil types in all three sampling stages, but tissue total $\mathrm{N}$ concentrations were higher on organic soil in most cases (Table $5)$. Consequently, readings did not accurately reflect the nitrogen status in at least one of the two sites. One explanation could be that chlorophyll levels plateau at nitrogen levels above what is needed for optimal crop growth, since sufficient $\mathrm{N}$ was apparently present in both crops. The differences in carrots between soil types might also have been affected by growth stage. Due to a lack of defined carrot growth stages, carrots were sampled at three times during the growing season based on plant size and days after seeding. However, differences between sites and years in climate and soil conditions caused variability in the rate of development of the plant. Even at similar days after seeding, the carrots may have been at completely different development phases and tissue $\mathrm{N}$ concentrations. A lack of agreement of SPAD readings was also evident in cabbage and onions at maturity, which was also a less defined growth stage (Tables 3 and 4).

Differences in cultivar were also observed. Spanish onions on mineral soil had consistently higher SPAD values at all growth stages than yellow cooking onions on organic soil (Table $4)$. The differences were mainly due to thicker leaves of spanish onions compared to yellow cooking onions. However, we are unable to separate the effect of cultivar from the effect of soil type. A downy mildew (Peronospora destructor) outbreak on onions at maturity in 2000 on organic soil also significantly reduced SPAD values to below the 2001 readings even though total $\mathrm{N}$ concentrations were higher in 2000 (Table 4). Thus, any additional pest stresses on the plants also affect meter readings, causing problems for 
comparison of readings within or across years or sites. It was not possible to determine critical SPAD readings that could be consistently used for $\mathrm{N}$ management of cabbage, onions, or carrots.

Although the conditions under which we tested the SPAD meter for scheduling fertilizer application were not ideal, there appears to be potential for scheduling sidedress $\mathrm{N}$ using a well-fertilized reference plot. The effects of cultivar, soil type, climate, and plant stresses can all be reduced as potential complicating factors under this system. For effective use of a well-fertilized reference plot, SPAD readings have to reach a plateau in adequately fertilized crops.
The quadratic relationship in SPAD values among the $\mathrm{N}$ rates tested, as well as a nonsignificant relationship, that occurred in most cases suggest a plateau in readings occurred in these plots (Tables 3, 4, and 5). Although no $\mathrm{N}$ deficiency was observed in most of the plots, leaf SPAD readings were lower in the no $\mathrm{N}$ treatments than the high $\mathrm{N}$ treatments in about one third of the cases (Tables 3, 4, and 5 ). This suggests the plateau in SPAD readings was above the rates necessary to maximize yield. This could cause over-application of $\mathrm{N}$ if application was based on comparison to a well-fertilized reference plot, because adequately fertilized plants could be determined to be deficient in $\mathrm{N}$ in some instances. In most other instances, significant fertilizer savings are possible through the reduction in preplant applications, but suitable procedures for the scheduling of fertilizer applications based on SPAD readings need to be established.

Cardy meter $\mathrm{NO}_{3}-\mathrm{N}$ Readings. $\mathrm{NO}_{3}-\mathrm{N}$ concentrations as determined by the Cardy meter were highly variable among soil types, years, and growth stages (Tables 6, 7, and 8). Generally, $\mathrm{NO}_{3}-\mathrm{N}$ concentrations in the sap decreased during the growing season (Tables 6, 7, and 8) and increased with increasing $\mathrm{N}$ rate beyond the level of $\mathrm{N}$ sufficiency. $\mathrm{NO}_{3}-\mathrm{N}$ concentrations were often higher on mineral soil than on organic soil for onions and carrots in 2000 , but the opposite was true in

Table 5. Comparison of SPAD chlorophyll meter readings to laboratory tissue total nitrogen (N) concentrations at three growth stages for carrots grown on mineral and organic soil in 2000 and 2001.

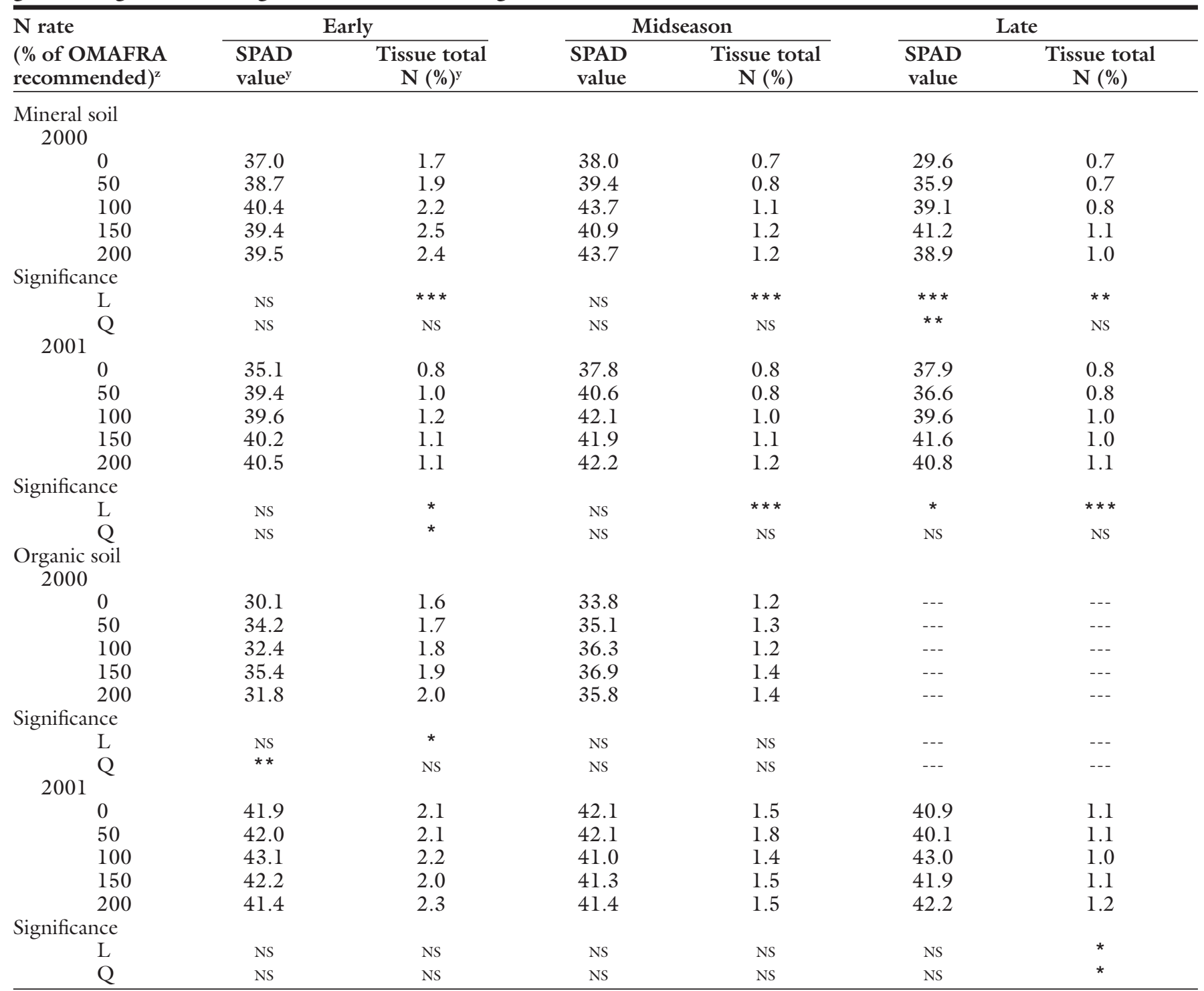

${ }^{2}$ OMAFRA = Ontario Ministry of Agriculture, Food, and Rural Affairs, 2000.

'SPAD value $=$ Minolta SPAD -502 chlorophyll meter reading; tissue total $\mathrm{N}$ = percent tissue total $\mathrm{N}$ content on a dry weight basis as determined by a laboratory.

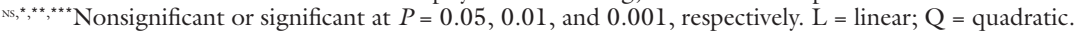


Table 6. Comparison of Cardy meter sap nitrate- $\mathrm{N}$ readings to laboratory tissue nitrate- $\mathrm{N}$ concentrations at three growth stages for cabbage grown on mineral soil in 2000 and 2001.

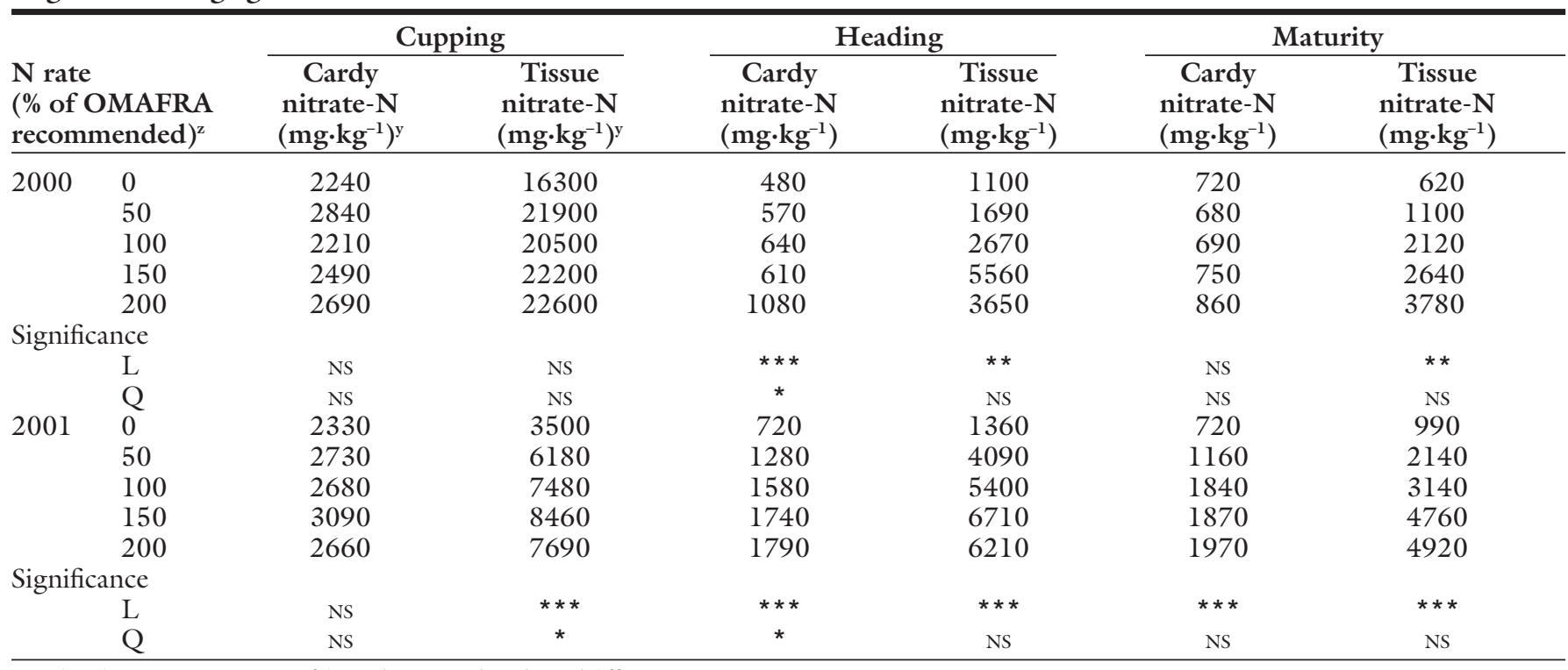

${ }^{2}$ OMAFRA = Ontario Ministry of Agriculture, Food, and Rural Affairs, 2000.

y Cardy nitrate- $\mathrm{N}=$ sap nitrate concentration as determined by a Cardy model C-14l nitrate meter; tissue nitrate- $\mathrm{N}=$ tissue nitrate concentration on a dry weight basis as determined by a laboratory; $1 \mathrm{mg} \cdot \mathrm{kg}^{-1}=1 \mathrm{ppm}$.

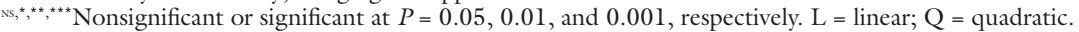

Table 7. Comparison of Cardy meter sap nitrate- $\mathrm{N}$ readings to laboratory tissue nitrate- $\mathrm{N}$ concentrations at three growth stages for onions grown on mineral and organic soil in 2000 and 2001.

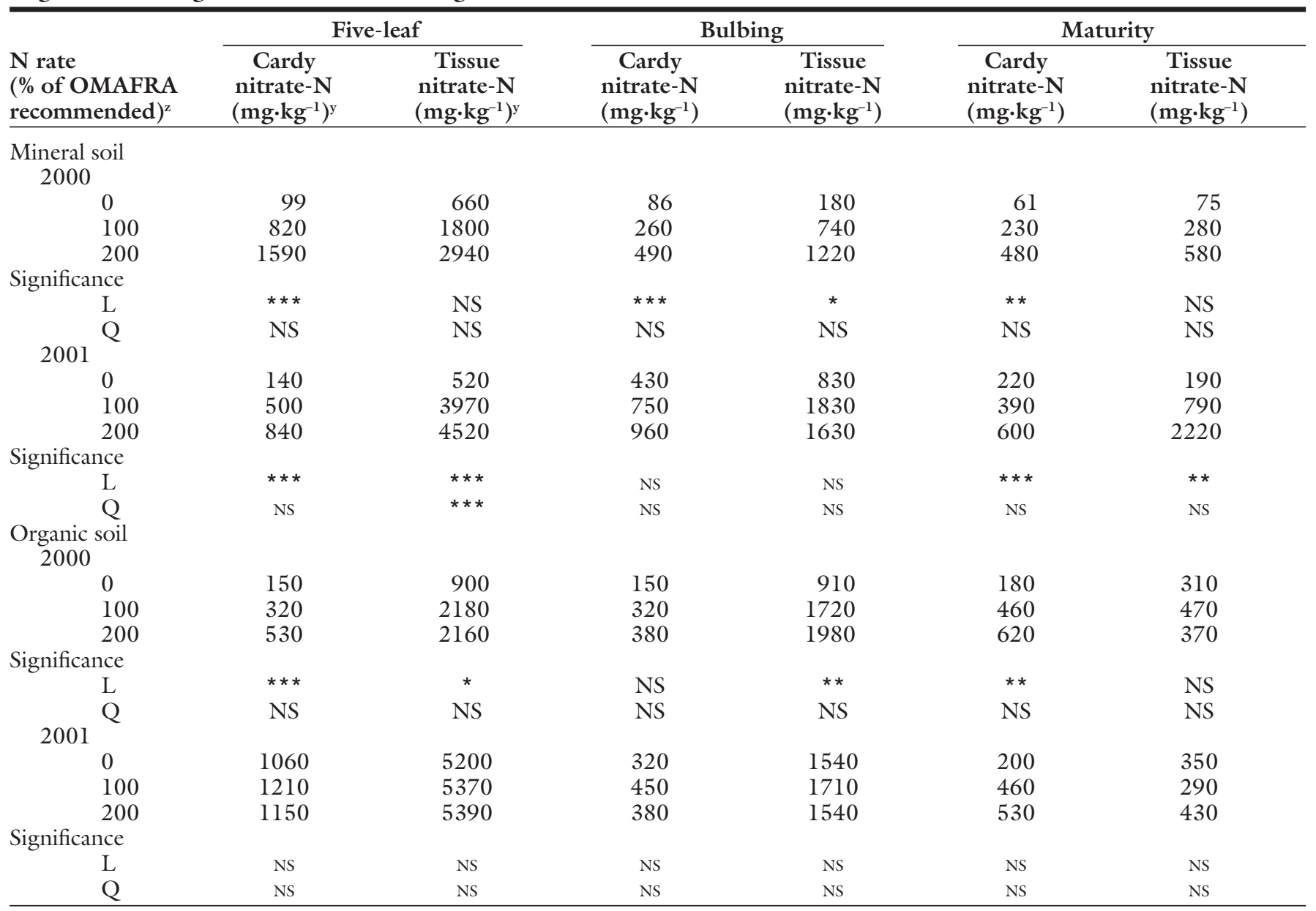

${ }^{2}$ OMAFRA = Ontario Ministry of Agriculture, Food, and Rural Affairs, 2000

y Cardy nitrate- $\mathrm{N}=$ sap nitrate concentration as determined by a Cardy model C-14l nitrate meter; tissue nitrate- $\mathrm{N}=$ tissue nitrate concentration on a dry weight basis as determined by a laboratory; $1 \mathrm{mg} \cdot \mathrm{kg}^{-1}=1 \mathrm{ppm}$.

Ns, ${ }^{*},{ }^{* *},{ }^{* \star *}$ Nonsignificant or significant at $P=0.05,0.01$, and 0.001 , respectively. $\mathrm{L}=$ linear; $\mathrm{Q}=$ quadratic. 
Table 8. Comparison of Cardy meter sap nitrate- $\mathrm{N}$ readings to laboratory tissue nitrate- $\mathrm{N}$ concentrations at three growth stages for carrots grown on mineral and organic soil in 2000 and 2001.

\begin{tabular}{|c|c|c|c|c|c|c|}
\hline \multirow[b]{2}{*}{$\begin{array}{l}\mathrm{N} \text { rate } \\
(\% \text { of OMAFRA } \\
\text { recommended })^{\mathrm{z}}\end{array}$} & \multicolumn{2}{|c|}{ Early } & \multicolumn{2}{|c|}{ Midseason } & \multicolumn{2}{|c|}{ Late } \\
\hline & $\begin{array}{c}\text { Cardy } \\
\text { nitrate-N } \\
\left(\mathrm{mg} \cdot \mathrm{kg}^{-1}\right)^{\mathrm{y}}\end{array}$ & $\begin{array}{c}\text { Tissue } \\
\text { nitrate-N } \\
\left(\mathrm{mg}^{\mathrm{m}} \mathrm{kg}^{-1}\right)^{\mathrm{y}}\end{array}$ & $\begin{array}{c}\text { Cardy } \\
\text { nitrate-N } \\
\left(\mathrm{mg}^{\circ} \mathrm{kg}^{-1}\right) \\
\end{array}$ & $\begin{array}{c}\text { Tissue } \\
\text { nitrate-N } \\
\left(\mathrm{mg}^{\mathrm{kgg}} \mathrm{kg}^{-1}\right) \\
\end{array}$ & $\begin{array}{c}\text { Cardy } \\
\text { nitrate-N } \\
\left(\mathrm{mg}^{\mathrm{kgg}} \mathrm{kg}^{-1}\right) \\
\end{array}$ & $\begin{array}{c}\text { Tissue } \\
\text { nitrate-N } \\
\left(\mathrm{mg} \cdot \mathrm{kg}^{-1}\right) \\
\end{array}$ \\
\hline \multicolumn{7}{|l|}{$\begin{array}{l}\text { Mineral soil } \\
2000\end{array}$} \\
\hline 0 & 810 & 3550 & 180 & 320 & 170 & 140 \\
\hline 150 & 1800 & 11000 & 760 & 3300 & 820 & 3040 \\
\hline 200 & 1310 & 11300 & 860 & 4420 & 570 & 1810 \\
\hline \multicolumn{7}{|l|}{ Significance } \\
\hline $\mathrm{L}$ & ** & $* * *$ & ** & $\star * *$ & ** & ** \\
\hline Q & * & NS & NS & NS & NS & NS \\
\hline \multicolumn{7}{|l|}{2001} \\
\hline 200 & 450 & 2100 & 360 & 1080 & 160 & 1080 \\
\hline \multicolumn{7}{|l|}{ Significance } \\
\hline $\mathrm{L}$ & ** & $* * *$ & $* * *$ & $* * *$ & NS & ** \\
\hline Q & NS & NS & NS & NS & NS & NS \\
\hline \multicolumn{7}{|l|}{$\begin{array}{l}\text { Organic soil } \\
2000\end{array}$} \\
\hline 0 & 300 & 3220 & 110 & 610 & --- & --- \\
\hline 50 & 380 & 3930 & 130 & 860 & --- & --- \\
\hline 100 & 490 & 4470 & 180 & 770 & --- & --- \\
\hline 150 & 490 & 5360 & 170 & 1160 & --- & --- \\
\hline 200 & 630 & 5740 & 230 & 1100 & --- & --- \\
\hline \multicolumn{7}{|l|}{ Significance } \\
\hline $\mathrm{L}$ & NS & ** & NS & NS & --- & --- \\
\hline $\mathrm{L}$ & NS & NS & NS & NS & NS & NS \\
\hline Q & NS & NS & NS & NS & NS & NS \\
\hline
\end{tabular}

${ }^{\mathrm{z}}$ OMAFRA = Ontario Ministry of Agriculture, Food, and Rural Affairs, 2000

${ }^{y}$ Cardy nitrate- $\mathrm{N}=$ sap nitrate concentration as determined by a Cardy model C-14l nitrate meter; tissue nitrate- $\mathrm{N}=$ tissue nitrate concentration on a dry weight basis as determined by a laboratory; $1 \mathrm{mg} \cdot \mathrm{kg}^{-1}=1 \mathrm{ppm}$.

Ns, ${ }^{* * *},{ }^{* * *}$ Nonsignificant or significant at $P=0.05,0.01$, and 0.001 , respectively. $\mathrm{L}=$ linear; $\mathrm{Q}=$ quadratic.

2001. These differences are probably the result of rapid $\mathrm{N}$ availability from fertilizer on mineral soil in 2000 due to above average rainfall, and poor $\mathrm{N}$ availability on mineral soil in 2001 due to minimal rainfall and soil moisture. In addition, $\mathrm{NO}_{3}-\mathrm{N}$ readings were often different at the same growth stages between the two years (Tables 6,7, and 8). This was probably due to lower rainfall and higher temperatures in 2001 than in 2000 , which would have altered the $\mathrm{N}$ availability in the soil.

Given the variability in readings among growth stages, soil types, and cultivars, it would be difficult to establish general critical Cardy $\mathrm{NO}_{3}-\mathrm{N}$ readings that would be effective for $\mathrm{N}$ management in all situations. However, region-specific critical Cardy $\mathrm{NO}_{3}-\mathrm{N}$ readings appear to have potential for $\mathrm{N}$ management of these crops. There is agreement in the readings within the same growth stage for all crops between the two years. Based on the data from these plots, the critical Cardy $\mathrm{NO}_{3}-\mathrm{N}$ readings for cabbage are in the range of $2600 \mathrm{mg} \cdot \mathrm{kg}^{-1}(\mathrm{ppm})$ for the cupping stage and $800 \mathrm{mg} \cdot \mathrm{kg}^{-1}$ for heading and maturity, because cabbage readings below these values corresponded with either lower yield or delayed maturity compared to cabbage with Cardy $\mathrm{NO}_{3}$ $\mathrm{N}$ readings above these values. Criti- cal concentrations for onions would have to be specified for Spanish and yellow cooking cultivars. The critical Cardy $\mathrm{NO}_{3}-\mathrm{N}$ readings are at or below 100,80 , and $60 \mathrm{mg} \cdot \mathrm{kg}^{-1}$ for spanish onions at the five-leaf, bulbing, and mature stages, respectively, and at or below $150 \mathrm{mg} \cdot \mathrm{kg}^{-1}$ for yellow cooking onions at all three growth stages. Critical Cardy $\mathrm{NO}_{3}-\mathrm{N}$ readings for carrots are at or below 300, 100, and $80 \mathrm{mg} \cdot \mathrm{kg}^{-1}$ for the early, midseason, and late growth stages, respectively. However, since there was no yield response to increasing $\mathrm{N}$ rates in onions and carrots, it is difficult to establish precise critical Cardy $\mathrm{NO}_{3}-\mathrm{N}$ readings, 
Table 9. Cost comparison of in-field SPAD chlorophyll and Cardy nitrate meters to laboratory tissue or soil testing.

\begin{tabular}{lccc}
\hline Cost & $\begin{array}{c}\text { SPAD } \\
\text { chlorophyll } \\
\text { meter }(\$)\end{array}$ & $\begin{array}{c}\text { Cardy } \\
\text { nitrate } \\
\text { meter }(\$)\end{array}$ & $\begin{array}{c}\text { Laboratory } \\
\text { tissue } \\
\text { testing (\$) }\end{array}$ \\
\hline Initial & $1400^{\mathrm{z}}$ & 360 & 0 \\
Additional & 0 & $80^{\mathrm{y}}$ & $5-8^{\mathrm{x}}$ \\
After 100 samples & 1400 & 360 & $500-800$ \\
After 500 samples & 1400 & $520-760$ & $2500-4000$ \\
\hline
\end{tabular}

${ }^{\mathrm{z}}$ Costs in U.S. dollars in 2002.

yensors replaced every 200 samples tested (every 100 samples tested for carrots).

xer sample cost for total nitrogen and nitrate-nitrogen analysis only.

and consequently, these values should be further field tested to confirm their accuracy.

Scheduling $\mathrm{N}$ application using a well-fertilized reference plot would not be practical with the Cardy $\mathrm{NO}_{3}^{-}$meter. Nitrate- $\mathrm{N}$ concentrations in the sap increased linearly with $\mathrm{N}$ rate in most cases, even when there appeared to be $\mathrm{N}$ sufficiency based on yield results. Consequently, it would not be possible to determine whether the reference plot had sufficient or excessive $\mathrm{N}$ under this system.

The use of the Cardy $\mathrm{NO}_{3}^{-}$meter should be as practical as laboratory testing, as long as suitable procedures for its use are established. However, problems with the use of laboratory $\mathrm{NO}_{3}-\mathrm{N}$ testing and critical $\mathrm{NO}_{3}-\mathrm{N}$ concentrations have also been recently shown for these vegetable crops (Westerveld et al., 2003c), and the recommendation after this study was that critical tissue $\mathrm{NO}_{3}-\mathrm{N}$ concentrations should be established for regional conditions. Consequently, it appears that the use of tissue $\mathrm{NO}_{3}-\mathrm{N}$ concentrations for $\mathrm{N}$ management, regardless of the method of testing, requires region-specific critical concentrations.

Meter use. In general, the SPAD chlorophyll meter was easy to use. However, specific problems with the leaf and canopy structure of the crops interfered with accurate testing. For cabbage, leaf veins that were within the sensing area caused low readings. However, the affected readings were easy to detect and correct. As the plants reached maturity, readings were often above 50 SPAD units, which are considered to be slightly less accurate based on the meter specifications.

Due to the tube shaped onion leaves, light transmittance through the interior of the leaf could result in excess light entering the sensing area, and a failure of the meter to register a reading. It was possible to attain readings through protection of the sensing area from direct sunlight. Due to the thickness of the leaves at maturity, readings were above 50 SPAD units in most cases, especially for spanish onions, resulting in slightly reduced accuracy. Sap which exuded from the pressed leaves often accumulated on the meter, necessitating more frequent meter cleaning.

Carrot leaf chlorophyll content was very difficult to assess using the SPAD chlorophyll meter. Carrot leaves are finely dissected, and similar in width to the sensing area of the meter. While an accurate reading was possible, it was difficult to determine whether the sensing area was properly placed over the leaf. Consequently, meter readings could be lower than the actual chlorophyll levels of the leaf. It was difficult to determine which readings were not accurate in order to correct them. Leaf veins in the center of the leaf also altered readings. A much greater number of readings would be required to reduce this variability and attain accurate readings. Carrot leaf readings, when properly assessed, were often below 50 SPAD units, resulting in more accurate SPAD values.

Sap analysis with the Cardy $\mathrm{NO}_{3}{ }^{-}$meter was possible without any major problems. However, the lifespan of the replaceable sensor was reduced when carrot sap was tested. Residual $\mathrm{NO}_{3}-\mathrm{N}$ gradually accumulated on the sensing area after repeated carrot sap testing. This reduced the lifespan of the sensor by approximately 100 readings and increased the time required to clean the sensor between readings.

TIME REQUIREMENTS. SPAD chlorophyll meter results can be available in less than $\mathrm{l} \mathrm{h}$ as opposed to the several days it can take for laboratory results to come back. An accurate analysis of the cabbage and onion crops required the use of 40 readings per treatment. The time required for the test was around 5 min for cabbage and 10 min for onions.

The use of the Cardy $\mathrm{NO}_{3}{ }^{-}$meter for sap analysis was more time consuming than the SPAD meter. A suitable analysis of a treatment or site required 16 readings. The time required for these readings ranged from $20 \mathrm{~min}$ for cabbage to $30 \mathrm{~min}$ for onions and carrots.

Cost. Compared with laboratory tissue analysis, the Cardy $\mathrm{NO}_{3}^{-}$and SPAD chlorophyll meters have a high initial cost (Table 9). The SPAD chlorophyll meter is more expensive than the Cardy $\mathrm{NO}_{3}^{-}$meter, but has no additional costs. The Cardy $\mathrm{NO}_{3}^{-}$meter requires replacement of the sensor periodically. However, the cost of the Cardy $\mathrm{NO}_{3}^{-}$meter would not exceed the cost of the SPAD meter until about 2000 samples were tested. In relation to laboratory analysis, both meters become more cost effective as the number of samples increases. After 500 samples, approximately the number of tests required to adequately manage two or three fields for about 5 years, the cost of laboratory analysis would greatly exceed the cost of both meters (Table 9).

\section{Conclusions}

The SPAD chlorophyll meter has potential for $\mathrm{N}$ management of cabbage and onions as long as procedures for scheduling fertilizer applications can be established. Chlorophyll testing with the meter is both cost effective in the long term and far more rapid than laboratory testing. The meter is less effective for carrots due to incompatibility with the leaf structure of the carrot crop. The most appropriate use of the SPAD chlorophyll meter under local conditions and in vegetable crops appears to be the use of a well-fertilized reference plot. A well-fertilized reference plot can reduce the numerous sources of variability that make reading comparison among soil types, cultivars, and locations difficult.

The Cardy $\mathrm{NO}_{3}{ }^{-}$meter has potential for crop $\mathrm{N}$ analysis of all three vegetable crops. It is cost-effective when more than 500 samples are tested, and more rapid than laboratory analysis. Use of a well-fertilized reference plot would be difficult with the Cardy $\mathrm{NO}_{3}^{-}$meter because readings appear to increase beyond sufficient levels due 
to luxury $\mathrm{N}$ consumption. Due to variability in readings among sites and soil types, critical $\mathrm{NO}_{3}-\mathrm{N}$ readings must be established under region-specific growing conditions and cultivars. However, due to the ease of use and low cost of the Cardy $\mathrm{NO}_{3}{ }^{-}$meter, region-specific critical readings could be established relatively quickly.

\section{Literature cited}

Blackmer, T.M. and J.S. Schepers. 1994. Techniques for monitoring crop nitrogen status in corn. Commun. Soil Sci. Plant Anal. 25:1791-1800.

Coltman, R.R. 1988. Yields of greenhouse tomatoes managed to maintain specific petiole sap nitrate levels. HortScience 23: 148-151.

Delgado, J.A. and R.F. Follett. 1998. Sap test to determine nitrate-nitrogen concentrations in aboveground biomass of winter cover crops. Commun. Soil Sci. Plant Anal. 29:545-559.

Dwyer, L.M., M. Tollenaar, and L. Houwing. 1991. A nondestructive method to monitor leaf greenness in corn. Can. J. Plant Sci. 71:505-509.

Follett, R.H., R.F. Follett, and A.D. Halvorson. 1992. Use of a chlorophyll meter to evaluate the nitrogen status of dryland winter wheat. Commun. Soil Sci. Plant Anal. 23: 687-697.

Geypens, M. and H. Vandendriessche. 1996. Advisory systems for nitrogen fertilizer recommendations. Plant Soil 181:31-38.

Hartz, T.K., R.F. Smith, M. LeStrange, and K.F. Schulbach. 1993. On-farm monitoring of soil and crop nitrogen status by nitrateselective electrode. Commun. Soil Sci. Plant Anal. 24:2607-2615.

Kubota, A., T.L. Thompson, T.A. Doerge, and R.E. Godin. 1996. A petiole sap nitrate test for cauliflower. HortScience 31: 934-937.

Kubota, A., T.L. Thompson, T.A. Doerge, and R.E. Godin. 1997. A petiole sap nitrate test for broccoli. J. Plant Nutr. 20: 669-682.

Lopez-Cantarero, I., F.A. Lorente, and L. Romero. 1994. Are chlorophylls good indicators of nitrogen and phosphorus levels? J. Plant Nutr. 17:979-990.

Maynard, D.N. and A.V. Barker. 1972. Nitrate content of vegetable crops. HortScience 7:224-226.

Maynard, D.G. and Y.P. Kalra. 1993. Nitrate and exchangeable ammonium nitrogen, $\mathrm{p}$. 25-38. In: Carter, M.R. (ed.). Soil Sampling and Methods of Analysis. Canadian Society of Soil Science, Pinawa, Manitoba.
Neilsen, D., E.J. Hogue, G.H. Neilsen, and P. Parchomchuk. 1995. Using SPAD-502 values to assess the nitrogen status of apple trees. HortScience 30:508-512.

Ontario Ministry of Agriculture, Food, and Rural Affairs. 2000. Vegetable production recommendations. Publ. 363. Queen's Printer for Ontario, Toronto.

Reeves, D.W., P.L. Mask, C.W. Wood, and D.P. Delaney. 1993. Determination of wheat nitrogen status with a hand-held chlorophyll meter: influence of management practices. J. Plant Nutr. 16:781-796.

Rodriguez, I.R. and G.L. Miller. 2000. Using a chlorophyll meter to determine the chlorophyll concentration, nitrogen concentration, and visual quality of St. Augustinegrass. HortScience 35:751-754.

Rosen, C.J., M. Errebhi, and W. Wang. 1996. Testing petiole sap for nitrate and potassium: Acomparison of several analytical procedures. HortScience 31:1173-1176.

Sandoval-Villa, M., E.A. Guertal, and C.W. Wood. 2000. Tomato leaf chlorophyll meter readings as affected by variety, nitrogen form, and nighttime nutrient solution strength. J. Plant Nutr. 23:649-661.

Sullivan, D. 1986. Nitrogen management for seeded onions in northern Colorado. Onion World (Jan.):12.

Turner, F.T. and M.F. Jund. 1991. Chlorophyll meter to predict nitrogen topdress requirement for semidwarf rice. Agron. J. 83:926-928.

Warncke, D.D. 1996. Soil and plant tissue testing for nitrogen management in carrots. Commun. Soil Sci. Plant Anal. 27: 597-605.

Westcott, M.P., C.J. Rosen, and J.M. Wraith. 1993. Direct measurement of petiole sap nitrate in potato to determine crop nitrogen status. J. Plant Nutr. 16:515-521.

Westerveld, S.M., A.W. McKeown, C.D. Scott-Dupree, and M.R. McDonald. 2003a. Chlorophyll and nitrate meters as nitrogen monitoring tools for selected vegetables in Southern Ontario. Acta Hort. (in press).

Westerveld, S.M., M.R. McDonald, C.D. Scott-Dupree, and A.W. McKeown. 2003b. Optimum nitrogen fertilization of summer cabbage in Ontario. Acta Hort. (in press).

Westerveld, S.M., A.W. McKeown, C.D. Scott-Dupree, and M.R. McDonald. 2003c. How well do critical nitrogen concentrations work for cabbage, carrot, and onion crops? HortScience (in press).

Wood, C.W., P.W. Tracy, D.W. Reeves, and K.L. Edmisten. 1992. Determination of cotton nitrogen status with a handheld chlorophyll meter. J. Plant Nutr. 15: 1435-1448. 